\title{
GNA11 Gene Expression Analysis
}

National Cancer Institute

\section{Source}

National Cancer Institute. GNA11 Gene Expression Analysis. NCI Thesaurus. Code C89712.

A laboratory assay to determine the status of the GNA11 gene which encodes guanine nucleotide-binding protein subunit alpha-11. 